Ekspansi: Jurnal Ekonomi, Keuangan, Perbankan dan Akuntansi

ISSN (Online): 2580-7668 ISSN (Print): 2085-5230

Vol. 11, No. 2 (November 2019), Hal. 269 - 283

\title{
PENGARUH TRANSAKSI NON TUNAI TERHADAP JUMLAH UANG BEREDAR DI INDONESIA TAHUN 2015- 2018 DENGAN INFLASI SEBAGAI VARIABEL MODERASI
}

\author{
Meilinda Nur Rasyida Fatmawati ${ }^{1}$, Indah Yuliana ${ }^{2}$ \\ ${ }^{1,2}$ Fakultas Ekonomi, Universitas Islam Negeri Maulana Malik Ibrahim, Malang, Indonesia \\ Email Korespondensi: meilindanrf@gmail.com
}

\begin{abstract}
Nowadays, Non-cash transactions are increasingly used in transactions. Besides being more practical, easy and fast, non-cash transactions influence monetary policy in Indonesia. In monetary policy, non-cash transactions affect the level of money supply. Also besides, other factors can affect the money supply, namely inflation. Non-cash transactions in this study use a debit ATM, credit ATM, and electronic money. The purpose of this study is to obtain evidence of the effect of non-cash transactions on the money supply in Indonesia with inflation as a moderating variable during 2015-2018. Data collection is based on secondary data and the analysis technique used was Moderating Regression Analysis (MRA) test. Based on the results of research conducted, non-cash transactions have a positive and significant effect on the money supply and inflation can strengthen the relationship of non-cash transactions to the money supply.
\end{abstract}

Keywords: non-cash transactions; Debit ATM. ATM credit, electronic money, inflation, money supply (M1)

\begin{abstract}
Abstrak: Transaksi non tunai kini semakin banyak digunakan dalam bertransaksi. Selain lebih praktis, mudah dan cepat, transaksi non tunai memiliki pengaruh terhadap kebijakan moneter di Indonesia. Dalam kebijakan moneter, transaksi non tunai mempengaruhi tingkat jumlah uang beredar di masyarakat. Selain itu, terdapat faktor lain yang dapat mempengaruhi jumlah uang beredar yaitu inflasi. Transaksi non tunai pada penelitian ini menggunakan ATM debet, ATM kredit dan uang elektronik. Tujuan penelitian ini adalah untuk mendapatkan bukti pengaruh transaksi non tunai terhadap jumlah uang beredar di Indonesia dengan inflasi sebagai variabel moderasi selama tahun 2015-2018. Pengumpulan data menggunakan data sekunder dan teknik analisis yang digunakan adalah uji Moderating Regression Analysis (MRA). Berdasarkan hasil penelitian yang telah dilakukan adalah transaksi non tunai memiliki pengaruh positif dan signifikan terhadap jumlah uang beredar dan inflasi mampu memperkuat hubungan transaksi non tunai terhadap jumlah uang beredar.
\end{abstract}

Kata Kunci: transaksi non tunai; ATM debet. ATM kredit, uang eletronik, inflasi, jumlah uang beredar (M1)

DOI: $10.35313 /$ ekspansi.v11i2.1608

Riwayat Artikel:

Diterima: $05-11-2019$

Direvisi: 25 - 11 - 2019

Disetujui: 28-11 - 2019 


\section{PENDAHULUAN}

Sistem pembayaran di Indonesia kini semakin berkembang seiring dengan majunya teknologi. Kemajuan teknologi dan perubahan pola kehidupan masyarakat mendorong semakin berinovasinya penyelengaraan transaksi secara non tunai (Lintangsari et al, 2018) . Baik dalam jumlah volume (dalam satuan transaksi) dan nominal (dalam jutaan rupiah) transaksi non tunai mengalami perkembangan yang cukup signifikan dari tahun 2015- 2018 (bisa diihat di grafik 1.1). Awalnya, transaksi non tunai hanya dapat digunakan dengan sistem transfer antar bank maupun intra bank sendiri. Seiring bertambahnya inovasi perbankan, menambah macam pembayaran non tunai dengan menggunakan kartu diantaranya ATM debet, ATM kredit dan uang elektronik (e- money). Transformasi sistem pembayaran non tunai tersebut didukung juga oleh kebutuhan masyarakat dalam melakukan transaksi agar lebih praktis (Bambang et al, 2006).

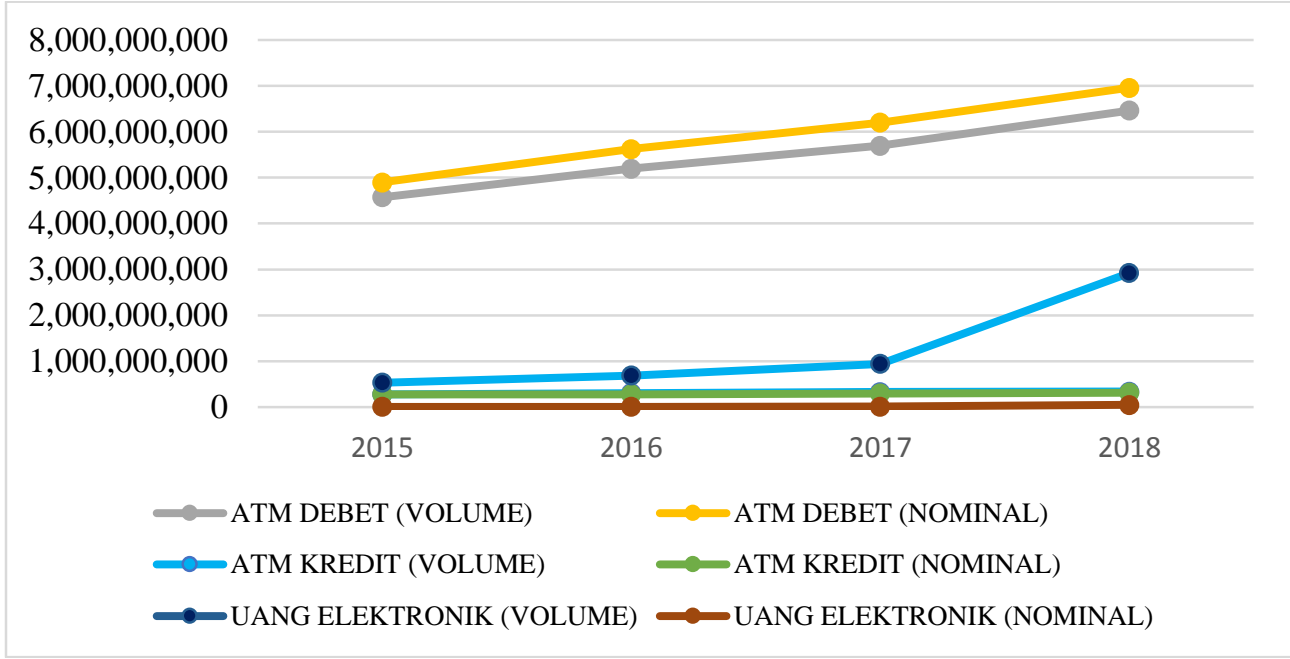

Sumber: Bank Indonesia 2015-2018 (Data Diolah)

\section{Gambar 1. Volume dan Nominal Transaksi Non Tunai 2015- 2018}

Ketiga instrumen transaksi non tunai selalu mengalami kenaikan dari tahun 20152018. Sehingga dapat diartikan bahwa masyarakat dapat menerima kehadiran transaksi non tunai dalam sebagian kegiatan transaksinya. Pada ATM Debet baik volume ataupun nilai transaksinya dari tahun 2015 hingga 2018 mengalami kenaikan sebesar 41\% dan 42\% sedangkan pada ATM Kredit, pada tahun 2015 hingga 2018 mengalami kenaikan sebesa $20 \%$ pada volume dan $12 \%$ pada nilai transaksinya. Peningkatan tersebut juga diprediksi dengan semakin banyaknya fasilitas/ fungsi dari kartu ATM yaitu tidak hanya digunakan untuk penarikan tunai atau pengecekan melainkan dapat juga digunakan untuk jenis pembayaran lainnya seperti pembayaran tagihan listrik, telepon dan lain- lain (Bambang et al, 2006). Hal tersebut juga didorong oleh majunya teknologi dan semakin maraknya pembayaran e-commerce menggunakan kartu (Lubis, 2019). Hal sama juga terjadi pada uang elektronik yang mengalami peningkatan besar pada volume transaksi yaitu sebesar $446 \%$ dan nilai transaksinya sebesar $793 \%$. Persentase yang besar tersebut didorong oleh faktor mudahnya uang elektronik dalam pembayaran- pembayaran mikro dan ritel secara lebih cepat daripada dengan 
pembayaran tunai (Agus et al, 2006). Di sisi lain, uang elektronik dapat diakses melalui smartphone yang dapat diakses kapan dan dimana saja seperti TCASH, Dompetku, XL Tunai, BBM Money, DoKu, OVO, Go- Pay, LinkAja, Dana dan lain-lain serta beberapa kegiatan uang elektronik menggunakan kartu yang diterbitkan oleh Bank Indonesia diantaranya Kartu Flazz dari BCA, kartu e-money dari Bank Mandiri, Kartu e-money Bank Mega, Kartu Brizzi dari BRI (Sofyan Abidin, 2015).

Peningkatan masyarakat dalam menggunakan transaksi non tunai dipacu oleh mudahnya dalam bertransaksi yang dapat mendorong penurunan biaya transaksi dan pada saatnya akan menstimulus pertumbuhan perekonomian. Selain lebih mudahnya dalam bertransaksi, bertransaksi non tunai juga diduga dapat mengurangi permintaan uang yang diterbitkan oleh bank sentral dan akan mempengaruhi pelaksanaan tugas bank sentral dalam pengendalian kebijakan moneter (Costa Storti \& De Grauwe, 2001). Otoritas moneter memperkirakan adanya transaksi non tunai akan menimbulkan transparansi dalam perputaran uang dan dapat memperlambat uang beredar. Artinya, semakin banyak tingkat penggunaan transaksi non tunai maka akan mengurangi jumlah permintaan uang (Bambang et al, 2006; Azka, 2017). Penelitian dari (Stix, 2004) yang meneliti pembayaran non tunai di Austria menghasilkan bahwa semakin banyak penggunaan transaksi non tunai maka akan mengurangi permintaan uang tunai, waktu untuk penarikan uang dan rata- rata cash holding.

Jumlah permintaan uang atau uang beredar yang ditentukan oleh Bank Indonesia ditentukan oleh tingkat harga barang/ jasa yang tersedia. Meningkatnya harga akan memicu naiknya permintaan jumlah uang di masyarakat (Ningsih \& Kristiyanti, 2019; Perlambang, 2017; Akinbobola, 2012). Kenaikan jumlah uang beredar di masyarakat juga disebabkan oleh meningkatnya tingkat konsumtif masyarakat yang tidak diimbangi dengan kenaikan jumlah barang/ jasa yang diproduksi yang mengakibatkan naik harga sebab kelangkaan terhadap barang/ jasa (Amrini, Aimon, \& Syofyan, 2015).

Tingginya harga secara keseluruhan dalam perekonomian sering disebut dengan inflasi. Menurut teori Mentores tentang inflasi menjelaskan bahwa adanya gejolak moneter disebabkan oleh tingginya jumlah uang beredar dan akan berdampak terhadap naiknya harga yang diakibatkan oleh ketidakseimbangan antara jumlah barang dan jumlah uang yang beredar di masyarakat. Inflasi akan mendorong naiknya upah dan berimbas pada naiknya harga. Inflasi yang terus meningkat merangsang tingkat kecenderungan berbelanja, terutama pada barang mewah dan primer. Hal tersebut menyebabkan tingkat jumlah uang di masyarakat bertambah banyak. Oleh sebab itu, inflasi akan mengganggu fungsi uang, terutama fungsi tabungan, fungsi pembayaran di muka dan fungsi perhitungan uang. Dapat dikatakan juga, tingkat inflasi yang semakin tinggi akan berdampak pada meningkatnya permintaan dan jumlah uang beredar pada masyarakat (Indah Yuliana, 2008 dan I Wayan Wenagama, 2019). Namun hal tersebut tidak sejalan dengan penelitian dari I B. Panji Sedana et al (2017) dan Susana Septeriani (2013). Kedua penelitian tersebut menjelaskan bahwa terdapat variabel lain yang lebih dapat mempengaruhi naik turunnya jumlah uang beredar. 
Untuk menjaga stabilitas sistem keuangan, Bank Indonesia selaku pelaku otoritas moneter menetapkan sasaran moneter agar kestabilan perekonomian Indonesia terjaga yaitu melalui jumlah uang beredar. Jumlah uang beredar di masyarakat perlu mendapatkan dukungan dari adanya sistem pembayaran. Sehingga, pembayaran non tunai saat ini menjadi hal yang perlu dipantau agar tidak berdampak negatif pada tujuan moneter. Peneliti tertarik meneliti transaksi non tunai sebagai variabel independen dan inflasi sebagai variabel moderating dengan alasan melihat upaya Bank Indonesia dan pemerintah dalam mengendalikan jumlah uang beredar melalui inflasi dan penerapan cashless yang di harapkan dapat mempertimbangkan jumlah uang beredar di masyarakat. Selain itu, kajian mengenai dampak transaksi non tunai terhadap jumlah uang beredar dan inflasi masih menjadi permasalahan terkini yang perlu dikaji kembali seiring dengan banyak munculnya financial technology (fintech) yang dapat mempengaruhi kondisi perekonomian Indonesia. Berbeda dengan penelitian dari Lintangsari et al (2018) menjelaskan bahwa transaksi elektronik dan ATM Debet berpengaruh signifikan terhadap uang beredar MI sedangkan ATM kredit tidak berpengaruh signifikan terhadap uang beredar MI. Namun, instrumen pembayaran non tunai akan tetap memberi dampak secara tidak langsung terhadap peningkatan jumlah uang beredar.

Atas ketidakkonsistenan hasil penelitian mengenai hubungan transkasi non tunai dan inflasi terhadap jumlah uang beredar, penelitian ini mencoba mengkaji kembali apakah inflasi dari waktu ke waktu dapat mempengaruhi jumlah uang beredar dan sebagai variabel moderating dapat memperkuat hubungan transkasi non tunai terhadap jumlah uang beredar. Dengan demikian, rumusan masalah dalam penelitian ini yaitu 1) apakah dengan meningkatkan jumlah transaksi non tunai dapat mengurangi jumlah uang beredar di masyarakat?; 2) apakah inflasi dapat memperkuat hubungan antara transaksi non tunai terhadap jumlah uang beredar?.

\section{TINJAUAN PUSTAKA}

\subsection{Hubungan Transaksi Non Tunai Terhadap Jumlah Uang Beredar}

Sistem pembayaran merupakan sistem yang digunakan untuk memindahkan sejumlah nilai uang dari pihak satu ke pihak lain. Sistem pembayaran di Indonesia terdiri dari sistem pembayaran tunai dan sistem pembayaran non tunai. Saat ini, uang kartal yang terdiri dari uang kertas dan logam menjadi alat pembayaran tunai pada masyarakat. Jumlah uang kartal dan uang logam yang dikeluarkan dan diedarkan oleh bank sentral disebut dengan mata uang peredaran. Sedangkan jumlah uang beredar merupakan seluruh jenis uang yang terdiri dari jumlah uang dalam peredaran ditambah dengan uang giral pada bank-bank umum. Uang beredar dibedakan menjadi pengertian yang sempit (M1) yang terdiri dari mata uang peredaran ditambah dengan uang giral yang dimiliki perorangan, perusahaan ataupun badan pemerintah dan pengertian yang luas (M2) yang terdiri dari mata uang dalam peredaran, uang giral dan uang kuasi (deposito berjangka, tabungan dan rekening valuta asing milik swasta domestik) (Sukirno, 2011). 
Sistem pembayaran dari waktu ke waktu mengalami kemajuan seiring dengan majunya teknologi yang membawa sistem pembayaran non tunai semakin sering digunakan. Selain didorong kebutuhan masyarakat atas transaksi yang lebih praktis, transaksi non tunai kini juga didorong oleh bank-bank sentral di dunia dengan alasan menginginkan sistem pembayaran yang relatif lebih aman, efektif dan efisien karena sistem transaksi yang lebih mudah, murah dan cepat sehingga dapat mempengaruhi produktivitas perekonomian Negara yang lebih baik (Lintangsari dkk., 2018). Instrumen pembayaran non tunai di Indonesia yang menggunakan kartu terdiri dari ATM (Automatic Teller Machine) yang berupa kartu debet, kartu kredit serta prepaid card dan electronic fund transfer (EFTS) atau point of sales (POS) (Bambang et al, 2006). Instrumen AMPK tersebut bersifat account based, sehingga bank memilih metode setelmen transaksi yang dilakukan masing- masing bank berbeda (sesuai dengan skala operasional jaringannya).

Transaksi non tunai telah menggeser peran uang tunai khususnya dalam perdagangan besar, transaksi keuangan dengan nilai besar dan dalam pembayaran retail dikarenakan semakin banyaknya pembayaran menggunakan metode transfer antar rekening bank dan semakin banyaknnya penggunaan kartu seperti debit, ATM kredit, e- money dalam bertransaksi (Lahdenpera, 2001). Selain dikarenakan lebih mudahnya dalam bertransaksi, transaksi non tunai juga diduga dapat mengurangi permintaan uang yang diterbitkan oleh bank sentral dan akan mempengaruhi pelaksaan tugas bank sentral dalam pengendalian kebijakan moneter (Costa Storti \& De Grauwe, 2001). Meningkatkan pembayaran non tunai akan berdampak terhadap permintaan uang dan keseimbangan pasar uang dan juga output dan harga yang mana akan berdampak terhadap kebijakan moneter (Nirmala \& Widodo, 2011).

Transaksi non tunai seperti penggunaan kartu, e-money ataupun elektronik transfer sebagai sistem pembayaran non tunai akan mengurangi permintaan dan kebutuhan dalam pemenuhan biaya dalam memelihara sejumlah likuiditas pada bank sentral dan dapat menurunkan kebutuhan atas permintaan uang kartal pada masyarakat (Bambang Widjajanta, 2007). Semakin banyak pengguaan transaksi non tunai memberikan pengaruh negatif signifikan terhadap jumlah uang yang beredar. Artinya, semakin banyak penggunaan transaksi non tunai maka akan mengurangi permintaan uang (Bambang et al, 2006; Yona Friantina, 2012; Azka, 2017; Aula Ahmad Hafidh \& Maimun, 2016). Kehadiran fasilitas kartu debet dan ATM menimbulkan kepercayaan masyarakat untuk menggunakan instrumen cashless secara lebih nyaman, cepat dan aman sehingga dapat mensubstitusi penggunaan uang kartal (Sahabat, 2009). Berdasarkan penelitian tersebut maka hipotesis kedua pada penelitian ini adalah:

$\mathrm{H}_{1}$ : Transaksi non tunai berpengaruh negatif signifikan terhadap jumlah uang beredar

\subsection{Moderasi Hubungan Inflasi Terhadap Transaksi Non Tunai dan Jumlah Uang Beredar}

Bank Indonesia sebagai bank sentral akan menentukan jumlah uang beredar yang ditentukan oleh faktor tingkat harga rata- rata dalam perekonomian (Ferdiansyah, 2016). Artinya, jumlah permintaan uang beredar pada masyarakat ditentukan oleh 
tingkat harga barang dan jasa yang tersedia. Semakin tinggi tingkat harga, maka semakin tinggi jumlah uang yang diminta dan sebaliknya. Kenaikan harga secara terus menerus dalam jangka waktu tertentu disebut inflasi

Dikatakan terjadi inflasi, apabila kenaikan harga tidak hanya terjadi pada satu atau dua barang/ jasa saja, akan tetapi bila kenaikan tersebut secara meluas atau menyebabkan kenaikan harga pada barang/ jasa lainnya (Bank Indonesia). Inflasi akan mengganggu taraf kemakmuran masyarakat dan menurunkan prosepek pembangunan ekonomi jangka panjang. Selanjutnya akan mengurangi ekspor, naiknya impor dan investasi produktif berkurang serta menghambat investasi sehingga memperlambat pertumbuhan ekonomi (Gerlach \& Tillmann, 2011 dan Maulida, Mardiana \& Mayes 2011).

Jika melihat teori kuantitas Irving Fisher menjelaskan bahwa semakin banyak jumlah permintaan uang maka akan meningkatkan inflasi. Hal tersebut mengilustrasikan dengan semakin banyaknya uang beredar di masyarakat maka akan meningkatkan minat masyarakat dalam berkonsumsi sehingga permintaan barang akan meningkat dan harga- harga barang pun akan semakin tinggi. Sehingga dapat dikatakan bahwa inflasi bersifat berbanding lurus dengan jumlah uang beredar. Artinya, naik turunya jumlah uang beredar juga dapat dipengaruhi oleh tingkat inflasi. Dengan tingkat harga yang terlalu tinggi memacu kenaikan upah yang akan menyebabkan masyarakat berbelanja barang dan jasa. Sehingga akan menaikkan tingkat jumlah uang beredar di masyarakat. Artinya, ketika terjadi inflasi atau naiknya harga- harga barang maupun jasa mengakibatkan permintaan jumlah uang beredar di masyarakat semakin meningkat (Indah Yuliana, 2008 dan I Wayan Wenagama, 2019).

Berdasarkan penelitian tersebut maka hipotesis kedua pada penelitian ini adalah:

$\mathrm{H}_{2}$ : Inflasi mampu memperkuat hubungan transaksi non tunai dengan jumlah uang beredar

\section{METODE PENELITIAN}

Penelitian ini termasuk penelitian kuantitatif dengan menggunakan penelitian eksplanatori yang bertujuan untuk menguji teori dan hipotesis yang telah berlaku selama ini apakah memperkuat atau bahkan memperlemah teori dan hipotesis pada penelitian sebelumnya. Penelitian ini menggunakan data time series bulanan dari tahun 2015- 2018 yang didapatkan dari Bank Indonesia dan Badan Pusat Statistik (BPS). Sehingga sampel yang dihasilkan yaitu berjumlah 48 bulan. Berikut persamaan regresi penelitian ini:

$$
Y=\alpha+\beta_{1} X+\beta_{2} Z+\beta_{3} X Z+e
$$

Dimana Y merupakan milyaran rupiah dari jumlah uang beredar (M1) yang terdiri dari jumlah uang kartal yang dipegang masyarakat ditambah dengan uang giral (giro berdenominasi Rupiah). Sedangkan pada variabel independen pada penelitian ini menggunakan jumlah transaksi non tunai (dalam jutaan rupiah) yang terdiri dari jumlah nominal ATM debet, ATM kredit dan uang elektronik serta variabel moderating penelitian ini menggunakan persentase inflasi per bulan. Analisis data yang digunakan berupa statistik deskriptif, uji asumsi klasik dan analisis regresi moderasi 
atau Moderating Regression Analysis (MRA) menggunakan program SPSS 16.0 . Kerangka konseptual penelitian ini digambarkan pada gambar 1.

Gambar 1. Kerangka Penelitian

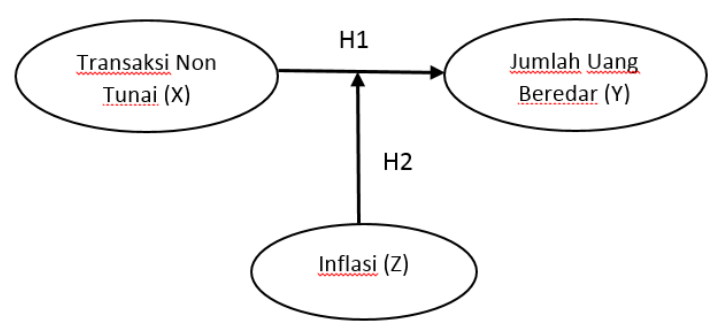

4. HASIL DAN PEMBAHASAN

\subsection{Statistik Deskriptif}

Berikut merupakan hasil olah data statistik deskriptif:

Tabel 1. Statistik Deskriptif Variabel Penelitian

\begin{tabular}{llllll}
\hline & N & Minimum & Maksimum & Mean & $\begin{array}{l}\text { Std. } \\
\text { Deviation }\end{array}$ \\
\hline Jumlah Uang Beredar (JUB) & 48 & 19,74 & 20,39 & 20,0576 & 0,14490 \\
Transaksi Non Tunai (TNT) & 48 & 13,73 & 14,19 & 13,9903 & 0,13447 \\
Inflasi (INF) & 48 & $(0,45)$ & 0,97 & 0,2702 & 0,32829 \\
TNT*INF & 48 & $(6,26)$ & 13,57 & 3,7853 & 4,58194 \\
Valid N (listwise) & 48 & & & & \\
\hline
\end{tabular}

Sumber: data diolah SPSS 16.0

Hasil dari tabel 1 menunjukkan bahwa pada sampel yang berjumlah 48 bulan tersebut menghasilkan pada variabel jumlah uang beredar (JUB) nilai rata-rata sebesar Rp20,05 milyar dengan jumlah minimum sebesar Rp19 milyar dan tingkat maksimum sebesar Rp20 milyar, variabel transaksi non tunai (TNT) memiliki nilai rata- rata sebesar Rp13,99 juta dengan tingkat minimum sebesar Rp13 juta dan nilai maksimum sebesar Rp20 juta, nilai rata- rata variabel inflasi (INF) sebesar 0,27 dengan minimum dan maksimum sebesar $-0,45$ dan 0,97 serta variabel interaksi (TNT*INF) memiliki nilai rata- rata sebesar Rp3,7 juta dengan nilai minimum dan maksimum sebesar R-6,2 juta dan Rp13 juta. Standar deviasi digunakan untuk mengetahui seberapa tingkat penyimpangan variabel yaitu menghasilkan nilai sebesar Rp0,14 milyar, Rp0,13 juta, 0,32 dan Rp4,5 juta untuk variabel JUB, TNT, INF dan interasi TNT*INF.

\subsection{Uji Asumsi Klasik}

Uji asumsi klasik digunakan untuk melihat apakah yang diestimasi telah memnuhi asumsi klasik dari OLS atau belum. Apabila lolos uji asumsi klasik maka tidak ada masalah dalam menggunakan metode OLS. Peneliti mengobati penelitian yang melanggar uji asumsi klasik dengan mengubah model regresi ke dalam bentuk logaritma natural $(\mathrm{Ln})$, sehingga model regresi penleitian menjadi seperti berikut:

$$
Y=\alpha+\beta_{1} \operatorname{LnX}+\beta_{2} \operatorname{LnZ}+\beta_{3} \operatorname{LnXZ}+e
$$

Kemudian hasil uji asumsi klasik setelah transformasi data disajikan dalam tabel di bawah ini: 
Tabel 2. Hasil Uji Asumsi Klasik

\begin{tabular}{|l|l|l|l|l|l|}
\hline $\begin{array}{l}\text { Parameter } \\
\text { yang diuji }\end{array}$ & $\begin{array}{l}\text { Uji } \\
\text { Normalitas }\end{array}$ & $\begin{array}{l}\text { Uji } \\
\text { Autokorelasi }\end{array}$ & \multicolumn{2}{|l|}{$\begin{array}{l}\text { Uji } \\
\text { Multikolinearitas }\end{array}$} & $\begin{array}{l}\text { Uji } \\
\text { Heterokedastisitas }\end{array}$ \\
\hline & $\begin{array}{l}\text { Asymp. Sig. (2- } \\
\text { tailed) }\end{array}$ & DW & Tolerance & VIF & Sig. \\
\hline $\begin{array}{l}\text { Unstandardized } \\
\text { Residual }\end{array}$ & 0,828 & & & & \\
\hline $\begin{array}{l}\text { LN_Transaksi } \\
\text { Non Tunai (LN_TNT) }\end{array}$ & & 0,985 & $\begin{array}{l}1,01 \\
5\end{array}$ & 0,132 \\
\hline LN_Inflasi (LN_INF) & & 9,087 & $\begin{array}{l}1,10 \\
1\end{array}$ & 0,187 \\
\hline LN_TNT*INF & & 0,985 & $\begin{array}{l}1,01 \\
5\end{array}$ & 0,933 \\
\hline Durbin-Watson & 2,019 & & & \\
\hline
\end{tabular}

Sumber: Data diolah SPSS 16.0

Uji normalitas digunakan untuk mengetahui normal atau tidaknya variabel independen, moderating dan dependen pada penelitian ini. uji normalitas menggunakan analisis Grafik Normal P- P Plot dan Kolmogorov-Smirnov Test yaitu menghasilkan uji normalitas sebagai berikut:

Normal P-P Plot of Regression Standardized Residual

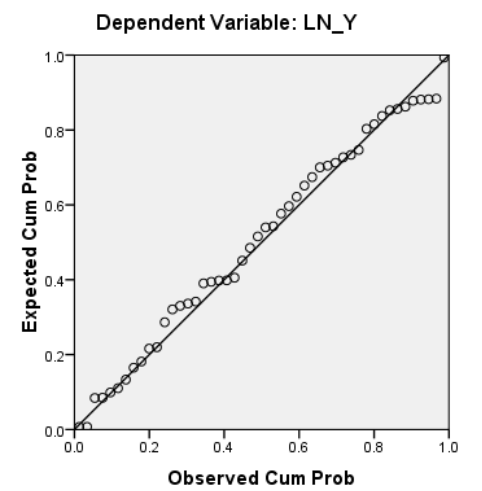

Sumber: Data Diolah

Gambar 2. Hasil Uji Normalitas

Dari hasil uji normalitas di atas diketahui bahwa pada Grafik Normal P. P Plot, data menyebar di sekitar garis diagonal dan mengikuti arah garis diagonalnya, maka model regresi memenuhi asumsi normalitas. Sedangkan berdasarkan tabel 2, Kolmogorov- Smirnov Test menghasilkan bahwa nilai sig.0,828> 0,05 yang artinya model regresi yang digunakan berditribusi normal.

Uji autokorelasi digunakan untuk mengetahui apakah terdapat korelasi antara kesalahan pengganggu pada periode $t$ dengan periode $t-1$. Hasil dari tabel 2 menunjukkan nilai DW sebesar 2,019 dengan nilai tabel DW signifikan 5\% dengan jumlah sampel (n) sejumlah 48 dan jumlah variabel bebas $(\mathrm{k})$ sebesar 1 maka diperoleh nilai dU sebesar 1,5776. Pengambilan keputusan didasarkan pada keputusan 
$\mathrm{dU}<\mathrm{DW}<4-\mathrm{dU}$ yaitu $1,5776<2,019<2,5072$ (4- 1,5776). Artinya, model regresi yang digunakan tidak mengandung autokorelasi baik positif maupun negatif.

Tabel 2 pada uji Multikolinearitas menghasilkan bahwa seluruh variabel independen baik variabel transaksi non tunai maupun inflasi memiliki nilai VIF $<10$ dan tolerance $>0$. Berdasarkan tabel 2 nilai tolerance variabel transaksi non tunai (LN_TNT), inflasi (LN_INF) dan interaksi transaksi non tunai dngan inflasi (LN_TNT*INF) masing- masing bernilai 0,985, 9,087 dan 0,985. Sedangkan nilai VIF tolerance variabel transaksi non tunai (LN_TNT), inflasi (LN_INF) dan interaksi transaksi non tunai dngan inflasi (LN_TNT*INF) yaitu bernilai 1,015, 1,101 dan 1,015. Sehingga berarti variabel independen yang digunakan tidak ada multikolinearitas atau tidak ada hubungan yang sangat kuat dengan variabel independen lainnya.

Hasil uji heteroskedastisitas dihasilkan pada grafik scatterplot di bawah ini:

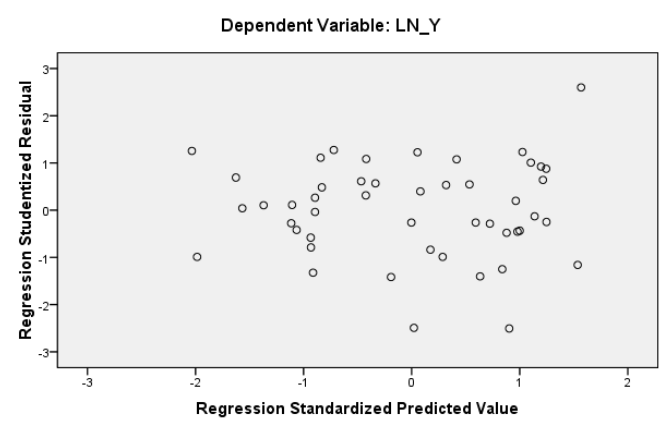

Sumber: data diolah SPSS 16.0

\section{Gambar 3. Hasil Uji Heteroskedastisitas}

Dari grafik scatterplots terlihat bahwa titik- titik dalam kotak menyebar di atas dan di bawah angka 0 pada sumbu Y. Hal ini dapat disimpulkan bahwa tidak terjadi heteroskedastisitas pada model regresi ini. Menurut tampilan pada tabel 1 memberikan koefisien parameter variabel dengan sig.> 0,05 atau tidak signifikan yaitu sebesar 0,132 untuk variabel transaksi non tunai (LN_TNT), 0,187 untuk variabel inflasi (LN_INF) serta 0,933 untuk variabel interaksi transaksi non tunai dengan inflasi. Maka dapat disimpulkan model regresi ini tidak terjadi heteroskedastisitas. Hal ini konsisten dengan uji grafik scatterplots.

\subsection{Pengujian Hipotesis}

Pengujian hipotesis penelitian ini menggunakan teknik analisis regresi moderasi atau Moderating Regression Analysis (MRA) melalui software SPSS 16.0 for windows. Analisis regresi moderasi atau Moderating Regression Analysis (MRA) digunakan untuk mengetahui hubungan variabel bebas (independen) terhadap variabel terikat (dependen) serta untuk mengetahui apakah variabel moderasi dapat memperkuat pengaruh variabel bebas terhadap variabel terikat. 
Pengujian hipotesis pertama dilakukan dengan mneggunakan regresi sederhana yaitu dapat dilihat pada tabel 3:

Tabel 3. Hasil Uji Hipotesis Pertama

\begin{tabular}{|c|c|c|c|c|}
\hline \multirow[t]{2}{*}{$\begin{array}{l}\text { Model Persamaan } 1 \\
(\mathrm{Y}=\alpha+\beta 1 \mathrm{X}+e)\end{array}$} & $\begin{array}{c}\text { Unstandardize } \\
\text { d Residual }\end{array}$ & $\begin{array}{c}\text { Standardized } \\
\text { Coefficients }\end{array}$ & \multirow[t]{2}{*}{$\mathbf{t}$} & \multirow[t]{2}{*}{ Sig. } \\
\hline & B & Beta & & \\
\hline Konstanta & 5,763 & & & 0,000 \\
\hline LN_Transaksi Non Tunai (LN_TNT) & 1,022 & 0,948 & 20,239 & 0,000 \\
\hline Adjusted R-Square & \multicolumn{4}{|l|}{0,897} \\
\hline
\end{tabular}

Sumber: data diolah SPSS 16.0

$$
\begin{aligned}
& Y=\alpha+\beta_{1} L N \_X+e \\
& Y=5,763+1,022 X+e
\end{aligned}
$$

Persamaan pada hipotesis pertama menghasilkan nilai sig.0,000<0,005 dan nilai beta unstandarlized residual 1,022 mengindikasikan bahwa transaksi non tunai memiliki pengaruh positif dan signifikan terhadap jumlah uang beredar, sehingga hipotesis pertama ditolak.

\section{Tabel 4. Hasil Analisis Regresi Moderasi sebagai Uji Hipotesis Kedua}

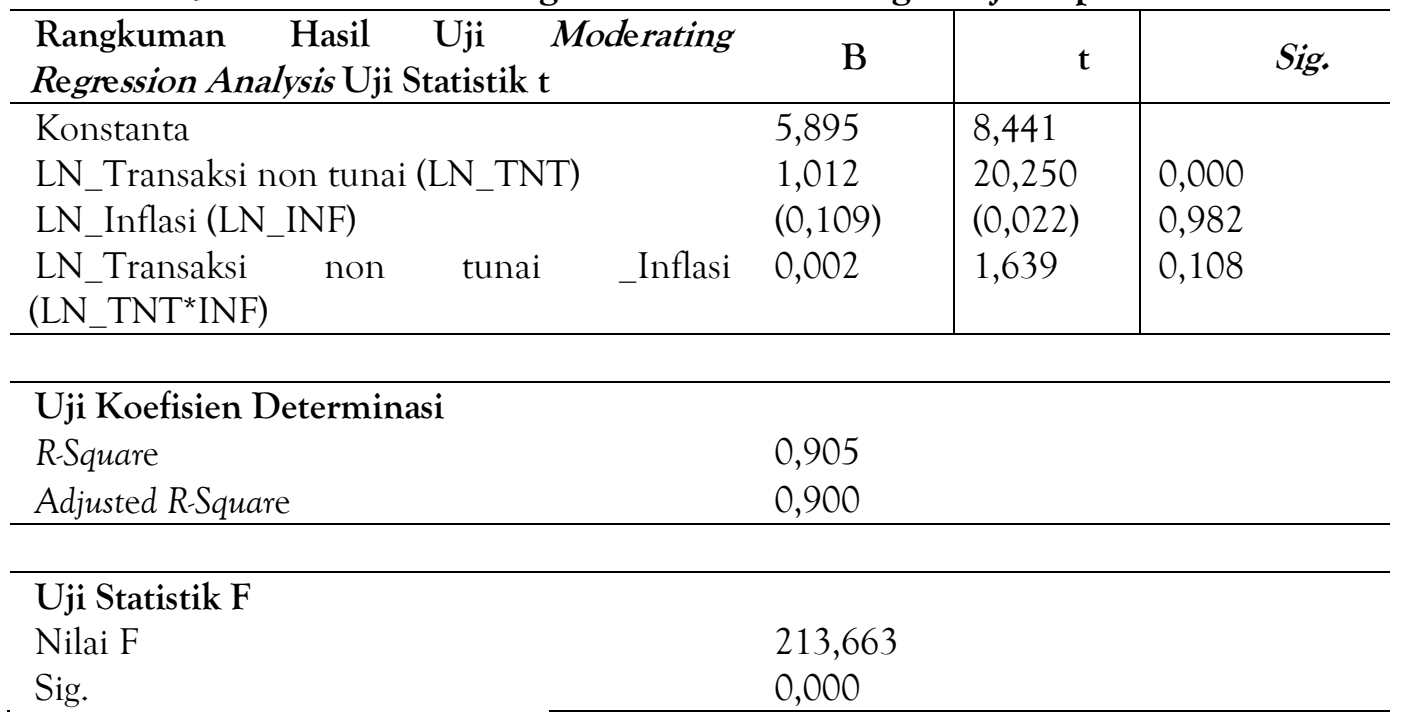

Sumber: data diolah SPSS 16.0

Berdasarkan tabel diatas, maka persamaan regresinya adalah sebagai berikut:

$\mathrm{Y}=\alpha+\beta_{1} \mathrm{LN} \_\mathrm{X}+\beta_{2} \mathrm{LN} \_\mathrm{Z}+\beta_{3} \mathrm{LN} \_\mathrm{XZ}+e$

$\mathrm{Y}=5,895+1,012 \mathrm{X}-0,109 \mathrm{Z}+0,002 \mathrm{XZ}+e$

Hasil uji- F (simultan) menghasilkan bahwa nilai signifikansi $F 0,000<0.05$, berarti model ini adalah layak. Variabel LN_TNT, LN_INF dan LN_TNT*INF memiliki pengaruh signifikan terhadap JUB.

Nilai adjusted R-Square pada penelitian ini bernilai 0,900 atau 90\%. Artinya, variabel transaksi non tunai (LN_TNT), inflasi (LN_INF) dan interaksi transaksi non tunai dan inflasi (LN_TNT $\left.{ }^{*} \mathrm{INF}\right)$ mampu menjalaskan variabel jumlah uang beredar 
(LN_JUB) sebesar 90\% serta dapat dikatakan sebesar 10\% dijelaskan oleh variabelvariabel di luar model penelitian.

Hasil dari Moderated Regression Analysis (MRA) menunjukkan bahwa koefisien $\beta 2$ dan $\beta 3$ dalam persamaan (3) dinyatakan tidak signifikan yaitu dengan nilai 0,982 dan 0,108. Oleh karena itu, variabel moderasi pada penelitian ini termasuk homologiser moderasi atau moderasi yang potensial menjadi variabel pemoderasi yang mempengaruhi kekuatan hubungan antara varaibel independen dan dependen.

Tabel 4 juga menghasilkan nilai Adjusted R-Square pada persamaan 1 dan 3 sebesar $89,7 \%$ dan $90 \%$. Hal tersebut mengindikasikan bahwa persamaan model 3 (setelah moderasi) lebih baik daripada model persamaan 1 (sebelum moderasi). Artinya, inflasi sebagai moderasi mampu memperkuat pengaruh transaksi non tunai terhadap jumlah uang beredar. Sehingga, hipotesis kedua diterima.

Sedangkan hasil uji- t (parsial), berdasarkan tabel 6 menghasilkan bahwa untuk variabel transaksi non tunai memiliki sig. sebesar $0,000<0,05$ dan thitung 20,250 yang artinya transaksi non tunai memiliki pengaruh positif dan signifikan terhadap jumlah uang beredar. Untuk variabel inflasi memiliki nilai sig. 0,982>0,05 dan thitung $-0,022$ mengartikan bahwa inflasi memiliki pengaruh negatif dan tidak signifikan terhadap jumlah uang beredar. Serta variabel interkasi transaksi non tunai dengan inflasi menghasilkan sig. 0,108>0,05 dan t hitung 1,639 yang menjelaskan bahwa variabel interaksi transaksi non tunai dengan inflasi memiliki pengaruh positif dan tidak signifikan terhadap jumlah uang beredar.

\subsection{Pembahasan}

Potensi transaksi non tunai dalam instrumen transaksi semakin diminati masyarakat di Indonesia. Peningkatan tersebut dibuktikan dalam peningkatan jumlah dan nominal transaksi non tunai secara signifikan dari tahun ke tahun (dilihat pada grafik 1). Selain mudah serta tuntutan masyarakat akan bertransaksi yang efisien dan aman, transaksi non tunai membawa pengaruh terhadap jumlah uang beredar yang ditentukan oleh Bank Indonesia. Tentunya, penggunaan transaksi non tunai dapat meningkatkan ataupun menurunkan tingkat jumlah uang yang beredar di masyarakat.

Hasil penelitian ini menunjukkan bahwa transaksi non tunai berpengaruh positif dan signifikan terhadap jumlah uang beredar. Artinya semakin tinggi penggunaan transaksi non tunai akan meningkatkan jumlah uang beredar di masyarakat. Dengan ditekannya penggunaan transaksi non tunai (cash-less society) oleh Bank Indonesia, masih belum memberikan dampak secara langsung terhadap jumlah uang beredar di masyarakat. Hal tersebut disebabkan oleh penggunaan transaksi non tunai hanya dilakukan untuk penarikan tunai karena masih banyaknya masyarakat yang awam terhadap penggunaan fasilitas transaksi non tunai serta masih banyak toko ataupun merchant yang menggunakan pembayaran tunai.

Pernyataan tersebut mendukung penelitian dari dari Siera (2006) juga menghasilkan hasil yang sama. Hasil penelitiannya membuktikan bahwa penggunaan transaksi non tunai di negara maju mampu mensubsitusikan pembayaran tunai dengan memanfaatkan pembayaran elektronik dalam bertransaksi. Namun, pembayaran tunai masih menjadi kebudayaan di Negara Indonesia. Keberadaan instrumen transaksi non 
tunai hanya mempermudah masyarakat dalam memperoleh uang tunai dan belum menjadi fasilitas pembayaran andalan dalam bertransaksi.

Penelitian lain dari Anderson-Reid (2008) juga mengasilkan hasil yang sama. Penelitian yang dilakukan di Jamaica menjelaskan bahwa dari tahun 2003- 2008 transaksi non tunai berupa ATM debit dan ATM kredit mengalami kenaikan yang signifikan dengan didukung semakin banyaknya fasilitas pembayaran non tunai. Hasilnya, meskipun penggunaan kartu debit dan kredit telah dilakukan dalam pembayaran ritel dan berkontribusi pada penurunan uang tunai yang dibuktikan dalam penurunan rasio uang (M1) namun uang kertas dan koin masih menjadi instrumen yang disukai masyarakat khususnya untuk ritel skala rendah. Kepemilikan kartu kredit hanya sebagai pola gaya hidup masyarakat walaupun pembayaran dalam jenis pembelian barang bernominal besar menggunakan kartu kredit (Snelman et al, 2000)

Fasilitas transksi non tunai di Indonesia khususnya pada toko- toko, ritel kecil dan pedagang lainnya masih belum menggunakan alat pembayaran non tunai. Meskipun penggunaan transaksi non tunai meningkat dari tahun ke tahun, namun belum berpengaruh terhadap peningkatan jumlah uang beredar di masyarakat. Pengguna kartu debit dan kredit harus melakukan penarikan uang untuk pembayaran tunai pada pada tempat yang masih melakukan transaksi secara tunai. Penelitian dari Lasondy\& Syarief (2015), Dias (2001) dan Yona Friantina (2012) juga mengatakan bahwa kenaikan transaksi atm debet, kredit dan e- money akan meningkatkan jumlah uang beredar. Berapapun uang kartal yang tergeser oleh transaksi non tunai, Bank Sentral tetap akan mengontrol keberadaan jumlah uang beredar melalui suku bunga jangka pendek (Woodford, 2000).

Hasil penelitian menunjukkan bahwa variabel inflasi mampu memperkuat dalam memoderasi hubungan transaksi non tunai terhadap jumlah uang beredar. Tingkat inflasi menjadi solusi masalah tingkat jumlah uang yang akan diedarkan pada masyarakat. Melalui inflasi, jumlah uang beredar dapat diperhatikan untuk dinaikan atau diturunkan oleh Bank Sentral. Kemudian, jumlah uang beredar akan menjadi target bagi operasional kebijakan moneter. Ketidakpastian tingkat inflasi juga memberikan dampak terhadap permintaan jumlah uang tunai sehingga para ekonom memilih untuk mengurangi jumlah uang beredar karena pada tingkat inflasi yang tinggi, masyarakat lebih memilih untuk menyimpan uang ke dalam asset- asset yang memiliki risiko yang lebih rendah (Ebrahim et al, 2014).

Inflasi harus lebih diperhatikan dengan tetap menstabilkan harga- harga barang dan jasa agar kebutuhan uang pada masyarakat pun terjaga. Begitupun sebaliknya, berdasarkan teori Irving Fisher, apabila jumlah uang beredar terjaga maka akan menstabilkan permintaan akan barang dan jasa dan harga- harganya. Secara sistematis, jumlah uang beredar berbanding lurus dengan tingkat harga atau inflasi. Maka dapat dikatakan bahwa inflasi juga dapat mempengaruhi tingkat jumlah uang beredar.

Negara yang memiliki tingkat inflasi tinggi akan mendorong permintaan uang pada masyarakat semakin tinggi. Hasil penelitian ini sejalan dengan penelitian dari Indah Yuliana (2008) dan I Wayan Wenagama (2019) yang menghasilkan bahwa 
jumlah permintaan uang pada masyarakat ditentukan oleh tingkat harga barang dan jasa. Hal tersebut mendukung teori Monetaris inflasi yang menyatakan bahwa gejolak moneter hanya terjadi karena tingginya jumlah uang beredar dan menyebabkan tingginya harga akibat dari tidak seimbangnya jumlah barang dan jumlah uang beredar.

\section{PENUTUP}

Berdasarkan hasil pembahasan penelitian ini dapat disimpulkan bahwa, transaksi non tunai berpengaruh positif dan signifikan terhadap jumlah uang beredar. Serta inflasi sebagai variabel moderasi berperan sebagaai moderasi potensial yang dapat memperkuat hubungan transaksi non tunai terhadap jumlah uang beredar. Adanya inflasi mencerminkan bahwa tingkat jumlah uang beredar yang akan diedarkan pada masyarakat dapat ditentukan melalui tingkat inflasi yang terjadi pada periode yang terjadi. Inflasi yang diindikasikan melalui tingkat harga barang- barang dan jasa menjadi tolak ukur berapa jumlah uang yang akan diedarkan pada masyarakat. Sehingga ini menjadi tugas bagi Bank Indonesia untuk lebih memperhatikan inflasi yang terjadi, agar jumlah uang yang akan diedarkan pada masyarakat sesuai dengan permintaan.

Transaksi non tunai yang digencarkan oleh Bank Indonesia melalui cash-less society perlu lebih diperhatikan dengan pemahaman masyarakat akan penggunaan instrumen transaksi non tunai. Agar penggunaan transaksi non tunai di Indonesia tidak hanya digunakan untuk penarikan tunai saja, melainkan digunakan dalam setiap transaksi. Dengan demikian, semakin banyaknya penggunaan transaksi non tunai dapat mengurangi jumlah uang beredar di masyarakat. Keterbatasan penelitian ini dalam penggunaan variabel yang masih sederhana. Saran untuk penliti selanjutnya untuk memberikan variabel lain yang dapat mempengaruhi variabel dependennya. Serta peneliti dapat menambahkan tahun yang lebih panjang dengan metode penelitian yang lain.

\section{DAFTAR PUSTAKA}

Agus Firmansyah, Aulia Fadly, Isnu Yuwana Darmawan, \& Ida (2006). Kajian operasional e-money. Bank Indonesia.

Akinbobola, T. O. (2012). The dynamics of money supply, exchange rate and LN_INFlation in Nigeria. 2, 117-141. Journal of Applied Finance \& Banking.

Amrini, Y., Aimon, H., \& Syofyan, E. (2015). Analisis Pengaruh Kebijakan Moneter Terhadap Inflasi Dan Perekonomian Di Indonesia. Jurnal Kajian Ekonomi, 2(4).

Anderson-Reid, K. (2008). Estimating the Impact of the Alternative Means of Payment on Currency Demand in Jamaica.

Aprileven, H. P. (2015). Pengaruh Faktor Ekonomi Terhadap Inflasi Yang Dimediasi Oleh Jumlah Uang Beredar. Economics Development Analysis Journal, 4(1), 32-41.

Aula Ahmad Hafidh, S. F., \& Maimun, S. (2016). Analisis Transaksi Non-Tunai (LessCash Transaction) Dalam Mempengaruhi Permintaan Uang (Money Demand) Guna Mewujudkan Perekonomian Indonesia Yang Efisien. Dipresentasikan pada Seminar Nasional 2016, UNY. 
Azka, A. (2017). Pengaruh Penggunaan Alat Pembayaran Menggunakan Kartu Terhadap Jumlah Uang Beredar Di Indonesia (Periode 2015 - 2016).

Bambang Widjajanta, A. W. (2007). Ekonomi Eु Akuntansi: Mengasah Kemampuan Ekonomi. Bandung: PT Grafindo Media Pratama.

Costa Storti, C., \& De Grauwe, P. (2001). Monetary Policy in a Cashless Society (SSRN Scholarly Paper No. Centre for Economic Policy Research).

Dias, J. (2001). Digital Money: Review of Literature and Simulation of Welfare Improvement of This Technological Advance. (State University of Maringa, BRAZIL).

Ebrahim, Sayed, Fariba. 2014. The Effect Of Inflation Uncertainty On Money Demand In Islamic Republic Of Iran. International Journal Of Business And Social Science, Vol. 5 No. 2

Ferdiansyah, F. (2016). Analisis Pengaruh Jumlah Uang Beredar (M1), Suku Bunga SBI, Nilai Tukar Suku Bunga Deposito Terhadap Tingkat Inflasi. Media Ekonomi Universitas Trisakti, Vol. 19, No. 3, 43-68.

Gerlach, S., \& Tillmann, P. (2011). Inflation Targeting and Inflation Persistence in AsiaPacific (No. 252011). Diambil dari Hong Kong Institute for Monetary.

I B. Panji Sedana dan Luh Gede Sri Artini, J. A. M. (2017, Oktober 8). Pengaruh Tingkat Suku Bunga, Inflasi Dan Pertubuhan Gross Domestic Product Terhadap Jumlah Uang Beredar Di Timor-Leste. E-Jurnal Ekonomi dan Bisnis, Vol. 06 No.10. Universitas Udayana.

I Wayan Wenagama, K. S. S. (2019). Pengaruh Tingkat Suku Bunga, Tingkat LN_INFlasi, Kurs Dollar AS Terhadap Jumlah Uang Beredar Di Indonesia. E-Jurnal Ekonomi, Vol. 8, No. 4 Pp (703-940). Pembangunan Universitas Udayana.

Indah Yuliana, SE., MM. (2008). Analisis Pengaruh Inflasi, Tingkat Suku Bunga Sbi Dan Nilai Tukar Terhadap Jumlah Uang Yang Beredar Di Indonesia Periode 2001 S/D 2006 [IQTISHODUNA], Vol 4, No 1.

Lahdenpera, H. (2001). Payment and Financial Innovation, Reserve Demand and Implementation of Monetary Policy (SSRN Scholarly Paper No. ID 315479). Diambil dari Social Science Research Network website: https://papers.ssrn.com/abstract=315479

Lintangsari, N. N., Hidayati, N., Purnamasari, Y., Carolina, H., \& Ramadhan, W. F. (2018). Analisis Pengaruh Instrumen Pembayaran Non-Tunai Terhadap Stabilitas Sistem Keuangan Di Indonesia. Jurnal Dinamika Ekonomi Pembangunan, 1(1), 47-62. Lubis, N. (2019). Pengaruh Sistem Pembayaran Non-Tunai Pada Era Digital Terhadap Tingkat LN_INFlasi Di Indonesia.

Maulida, Y., Mardiana', \& Mayes, A. (2011). Pengaruh Defisit Anggaran, Jumlah Uang Beredar Dan Independensi Bank Indonesia Terhadap Inflasi. Jurnal Ekonomi, 19(01).

Ningsih, S., \& Kristiyanti, L. M. S. (2019). Analisis Pengaruh Jumlah Uang Beredar, Suku Bunga Dan Nilai Tukar Terhadap Inflasi di Indonesia Periode 2015-2016. Jurnal Manajemen Dayasaing, 20(2), 96-103-103. 
Nirmala, T., \& Widodo, T. (2011). Effect Of Increasing Use The Card Payment Equipment On The Indonesian Economy. Jurnal Bisnis Dan Ekonomi, 18(1), Hal. 36 - 45.

Perlambang, H. (2017). Analisis Pengaruh Jumlah Uang Beredar, Suku Bunga Sbi, Nilai Tukar Terhadap Tingkat Inflasi. Media Ekonomi, 18(2), 49.

Rossa, Siera. 2006. Analisis Pengaruh Penggunaan Kartu Pembayaran Elektronik Dan Daya Substitusi Transaksi Non Tunai Elektronik Terhadap Transaksi Tunai Indonesia. Ut Economic Science [2240]. IPB Repository.

Snellman, J, J. Vessel, dan D. Humphrey. 2000. "Substitution of Non Cash Payment Instrumens for Cash in Europe". Bank of Finland Discussion Paper. 9/2000.

Sofyan Abidin, M. (2015). Dampak Kebijakan E-Money Di Indonesia Sebagaialat Sistem Pembayaran Baru. Jurnal Akuntansi Akunesa, 3(2).

Stix, H. (2004). The Impact of ATM Transactions and Cashless Payments on Cash Demand in Austria. Monetary Policy $\mathbb{E}$ the Economy, (1), 90-105.

Sukirno, S. (2011). Makroekonomi Teori Pengantar Edisi Ketiga. Jakarta: PT Rajagrafindo Persada.

Susana Septeriani, S. S. (2013). Pengaruh Inflasi, Suku Bunga, Dan Produk Domestik Bruto Terhadap Jumlah Uang Beredar Di Indonesia Periode 1995-2011. Jurnal Curvanomic, 2(2).

Sutawijaya, A., \& Zulfahmi. (2015). Analisis Perilaku Inflasi Jangka Pendek Dan Jangka Panjang Atas Faktor - Faktor Penyebab Utama Di Indonesia [Monograph].

Syarief, Lasondy. 2015. Analisis Dampak Pembayaran Non Tunai Terhadap Jumlah Uang Beredar di Indonesia. Jurnal Ekonomi Dan Keuangan Vol.2 No.10.

Working paper: Dampak Pembayaran Non Tunai Terhadap Perekonomian Dan Kebijakan Moneter. 1-99.

Woodfoord, Michael, 2000. Monetary Policy In A World Without Money, National Bureau of Economic Research Working Paper, Nomor 7853.

Yona Friantina. (2012). Pengaruh Alat Pembayaran Elektronik Berbasis Kartu Terhadap Jumlah Uang Beredar (M1) dalam Sistem Pembayaran di Indonesia Periode April 2007. Desember 2011. 